\title{
TINGKAT STRES MAHASISWA S1 KEPERAWATAN TINGKAT SATU DALAM MENGHADAPI WABAH COVID 19 DAN PERKULIAHAN DARING DI STIKES KARYA HUSADA KEDIRI.
}

\section{STRESS LEVEL OF FIRST GRADE S1 NURSING STUDENT IN FACING COVID 19 AND ONLINE LECTURER AT KARYA HUSADA HEALTH INSTITUTE KEDIRI}

\author{
Melani Kartika Sari ${ }^{1 *}$ \\ ${ }^{1}$ STIKes Karya Husada Kediri \\ Korespondensi penulis: melastarte@gmail.com \\ ORCHID ID: 0000-0003-1886-0992
}

\begin{abstract}
Abstrak
Wabah Covid-19 merupakan jenis penyakit baru dan sangat mudah menular. Virus baru ini sebelumnya tidak dikenal sebelum menjangkit banyak penduduk Wuhan, Cina. Virus ini kini menyebar hampir ke seluruh dunia. Untuk menghambat penyebarannya, pemerintah menghimbau masyarakat untuk melakukan stay at home dan pembelajaran dilakukan secara daring. Tujuan penelitian ini adalah mengetahui tingkat stres mahasiswa tingkat satu prodi S1 Keperawatan Stikes Karya Husada dalam menghadapi wabah Covid-10 dan perkuliahan daring akibat wabah tersebut. Jenis penelitian ini adalah studi deskriptif dengan desain cross sectional. Pengambilan sampel dilakukan dengan teknik purposive sampling untuk mendapatkan jumlah sampel sebanyak 70 responden. Data dikumpulkan menggunakan kuesioner dalam bentuk google form dan didapatkan sebagian besar mahasiswa mengalami stres sedang (38,57\%), sebagian mengalami stres berat $(28,57 \%)$, dan stres ringan sebanyak $(32,86 \%)$. Stressor yang paling menyebabkan stres yaitu kesulitan memahami materi secara daring dan kekhawatiran tertular Covid-19. Kondisi wabah yang penuh dengan ketidakpastian ini perlu disikapi secara bijaksana oleh berbagai pihak. Perlu usaha untuk mereduksi stres dengan melakukan beragam aktivitas yang menyenangkan di dalam rumah yang bisa dilakukan oleh mahasiswa.
\end{abstract}

Kata kunci: tingkat stres, mahasiswa, covid-19, kuliah daring

\begin{abstract}
The Covid-19 outbreak is a new type of disease and is highly contagious. This new virus was previously unknown before infecting many residents of Wuhan, China. This virus is now spreading to most of the world. To prevent its spread, the government urges people to stay at home and learn online. The aimed of this study was to determine the level of stress of first-degree students in the Nursing Study Program at Stikes Karya Husada in dealing with the Covid-10 outbreak and online lectures due to the outbreak. This type of research is a descriptive study with cross sectional design. Sampling was done by purposive sampling technique to get a total sample of 70 respondents. Data were collected using a questionnaire in the form of google and found that most students experienced moderate stress (38.57\%), some experienced severe stress (28.57\%), and mild stress $(32.86 \%)$. The stressors that cause the most stress are difficulty understanding online material and worry about contracting Covid-19. Pandemic conditions that are full of uncertainty need to be addressed wisely by various parties. It takes effort to reduce stress by doing a variety of fun activities in the home that can be done by students.
\end{abstract}

Keywords: stress level, students, covid-19, online lectures

\section{Pendahuluan}

Corona virus merupakan sekelompok virus yang dapat menyebabkan penyakit pada hewan dan manusia. Beberapa jenis virus yang termasuk dalam golongan ini antara lain SARS (Severe Acut Respiratory Syndrome), MERS (Middle East Respiratory Syndrome), dan COVID-19 (WHO, 2020). Covid-19 
merupakan jenis penyakit baru dan sangat mudah menular. Virus baru ini sebelumnya tidak dikenal sebelum menjangkit banyak penduduk Wuhan, Cina dan menyebabkan wabah di sana pada Desember 2019. (Kemenkes, 2020)

Covid-19 sangat mudah menular melalui percikan batuk atau bersin. Percikan tersebut dapat menempel pada permukaan bendabenda kemudian dapat menular ke orang lain yang menyentuh permukaan yang terkontaminasi tersebut. Gejala utama para penderita yang terjangkit Covid-19 yaitu demam, batuk dan kesulitan bernapas (WHO, 2020).

Angka kejadian Covid-19 menurut data WHO per tanggal 27 April 2020 mencapai 2.883.603 orang dengan angka kematian mencapai 198.824. Sedangkan di Indonesia, jumlah penderita Covid-19 mencapai 9.069 orang dengan angka kematian sebesar 1.151 orang. Tingginya angka kejadian dan potensi kematian membuat banyak pihak berusaha memutuskan rantai penularan Covid-19 ini dengan berbagai cara, seperti penerapan PSBB, perubahan sistem sekolah dan perkuliahan menjadi system daring, dan himbauan kepada seluruh masyarakat untuk menggunakan masker.

Akibat pandemi global Covid-19 ini semua kampus digiring untuk melakukan perkuliahan daring atau online dalam rangka memutus mata rantai penyebaran Covid-19 (Tabroni, 2020). Semua elemen mulai dari dosen, ketenagaan, dan mahasiswa harus beradaptasi terhadap kondisi ini. Perubahan yang terjadi secara tiba-tiba ini tentu dapat menimbulkan stres tersediri bagi mahasiswa.

\section{Metode}

Jenis penelitian ini merupakan studi deskriptif. Penelitian ini dilakukan pada bulan April 2020 pada mahasiwa tingkat satu Program Studi S1 Ilmu Keperawatan Stikes Karya Husada Kediri.

Populasi penelitian yaitu seluruh mahasiswa tingkat satu program studi S1 Keperawatan Stikes Karya Husada Kediri sejumlah 89 mahasiswa. Sedangkan jumlah responden penelitian ini sejumlah 70 mahasiswa yang diambil menggunakan teknik sampling Purposive Sampling.

Kriteria inklusi dalam penelitian ini yaitu mahasiswa aktif tingkat satu program studi S1 Keperawatan yang bersedia menjadi responden penelitian. Sedangkan kriteria eksklusi dalam penelitian ini yaitu mahasiswa yang sedang sakit atau mengalami kondisi serius lainnya.

Data diperoleh melalui kuesioner dalam bentuk google form yang disebar ke mahasiswa melalui grup kelas secara daring. Kuesioner yang digunakan disusun oleh peneliti berdasar berbagai indikator stres yang berkaitan dengan kejadian pandemi Covid-19 dan perkuliahan daring akibat wabah tersebut. Data dianalisis secara statistik berdasarkan variabel yang diteliti menggunakan analisis univariat. Analisis univariat digunakan untuk menganalisis tingkat stres mahasiswa terkait wabah covid-19 dan perkuliahan daring akibat wabah tersebut. Kuesioner terdiri dari 20 item pertanyaan yang terdiri dari perasaan mudah tersinggung saat wabah Covid-19 mulai melanda, perasaan cemas ketika mendengar berita tentang Covid-19, rasa kesulitan menenangkan pikiran sejak ada wabah Covid19, perasaan kesal terhadap social distancing, perasaan sering merasa cemas, perasaan sering tidak sabar, perasaan mudah tersinggung, perasaan sulit beristirahat, perasaan gelisah, perasaan khawatir terhadap virus Covid-19, perasaan khawatir wabah tidak segera mereda, perasaan cemas saat keluar rumah saat social distancing, perasaan santai saat berada di dalam tempat tinggal, perasaan khawatir terjangkit virus Covid-19 saat berada di luar, rasa khawatir saat melihat orang lain batuk atau bersin, rasa tidak nyaman dengan perkuliahan daring, rasa terbebani dengan tugas perkuliahan daring, kesulitan mengerjakan tugas daring, kesulitan memahami materi kuliah secara daring, dan rasa bosan saat harus melakukan social distancing dan tidak boleh bepergian.

\section{Hasil}

Penelitian ini dilakukan pada mahasiswa aktif program studi S1 Keperawatan angkatan 2019 pada bulan April 2020.

Tabel 1. Karakteristik responden

\begin{tabular}{llll}
\hline & Karakteristik & f & \% \\
\hline Usia & 18 tahun & 22 & $31,4 \%$ \\
& 19 tahun & 38 & $54,28 \%$ \\
& 20 tahun & 8 & $11,42 \%$ \\
& 21 tahun & 2 & $2,85 \%$ \\
\hline \multicolumn{2}{c}{ Jumlah } & 70 & $100 \%$ \\
\hline Jenis & Pria & 10 & $14,3 \%$ \\
Kelamin $\quad$ Wanita & 60 & $85,7 \%$ \\
\hline \multicolumn{2}{c}{ Jumlah } & 70 & $100 \%$ \\
\hline
\end{tabular}




\begin{tabular}{llll}
\hline Tempat & Rumah & 62 & $88,57 \%$ \\
tinggal & Rumah & 4 & $5,7 \%$ \\
saat social & Saudara & 4 & $5,7 \%$ \\
distancing & Kos & & \\
\hline \multicolumn{2}{c}{ Jumlah } & 70 & $100 \%$ \\
\hline
\end{tabular}

Tabel 1 menunjukkan karakteristik responden yang terdiri dari usia, jenis kelamin dan lokasi tempat tinggal saat diberlakukan social distancing akibat wabah virus covid-19. Sebagian besar responden berusia 18 tahun, jenis kelamin terbanyak yaitu wanita, lokasi tempat tinggal terbanyak saat social distancing yaitu rumah.

Tabel 2. Gambaran Tingkat Stres Responden

\begin{tabular}{lcc}
\hline $\begin{array}{l}\text { Tingkat } \\
\text { Stres }\end{array}$ & $\mathbf{f}$ & \% \\
\hline $\begin{array}{l}\text { Stres } \\
\text { Ringan }\end{array}$ & 23 & 32,86 \\
\hline $\begin{array}{l}\text { Stres } \\
\text { Sedang }\end{array}$ & 27 & 38,57 \\
\hline Stres Berat & 20 & 28,57 \\
\hline Jumlah & 70 & $100 \%$ \\
\hline
\end{tabular}

Tabel 2 menunjukkan distribusi tingkat stres responden akibat wabah Covid-19 dan perkuliahan daring akibat wabah tersebut. Stressor berkaitan dengan kekhawatiran tertular Covid-19, kebosanan saat melakukan social distancing, kesulitan memahami materi perkuliahan daring, dan beban penugasan perkuliahan. Sebagian besar responden mengalami tingkat stres sedang $(38,57 \%)$. Tingkat stres diukur menggunakan kuesioner dengan kategori stres ringan $<56 \%$, stres sedang $56-75 \%$, dan stres berat $>75 \%$ dari jumlah total skor kuesioner.

Gambar 1. Distribusi Skor Tiap Pertanyaan Kuesioner

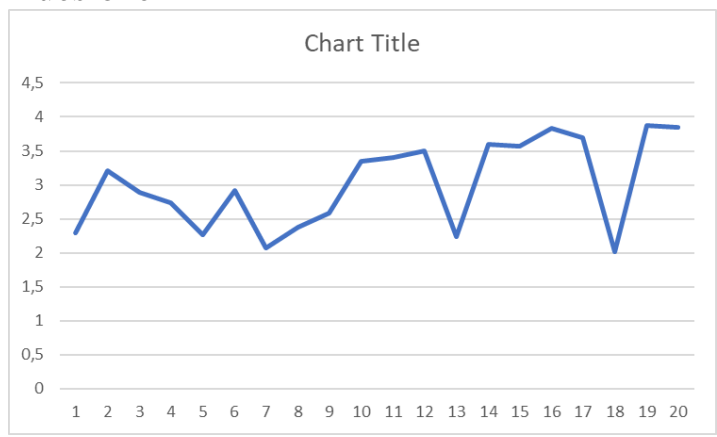

Pada gambar 1 diperoleh data bahwa skor rata-rata tertinggi terdapat pada pertanyaan nomor 19 yang dapat menyebabkan stres. Pertanyaan tersebut merupakan pertanyaan yang berkaitan dengan kesulitan memahami materi saat dilakukan perkuliahan secara daring. Hal ini menunjukkan bahwa item pertanyaan tersebut merupakan hal yang paling menyebabkan stres pada mahasiswa di masa pandemi Covid-19 ini.

\section{Pembahasan}

Karakteristik Responden

Data penelitian ini didapat dari 70 mahasiswa tingkat satu di prodi S1 Keperawatan Stikes Karya Husada Kediri yang memenuhi kriteria inklusi. Dari data didapatkan bahwa usia mayoritas responden adalah 18 tahun. Sedangkan jenis kelamin responden terbanyak adalah wanita. Sedangkan data tempat tinggal terbanyak saat dilakukan social distancing akibat Covid-19 yaitu di rumah.

\section{Gambaran Tingkat Stres Responden}

Sebagian besar responden pada penelitian ini mengalami tingkat stres dalam kategori sedang yaitu sebanyak 27 mahasiswa atau $(38,57 \%)$. Sedangkan 20 mahasiswa $(28,57 \%)$ mengalami stres tingkat berat, dan 23 mahasiswa $(32,86 \%)$ mengalami stres tingkat ringan.

Stres yang dialami mahasiswa akibat wabah Covid-19 ini dipengaruhi oleh beberapa hal. Beberapa hal yang menjadi stressor bagi mahasiswa ketika wabah Covid19 ini berlangsung yaitu adanya ketakutan tertular Covid-19, kekhawatiran saat pergi keluar rumah, kebosanan saat melakukan social distancing, dan kesulitan memahami materi saat perkuliahan daring.

Covid-19 memang mudah menular melalui percikan bersin, batuk, atau melalui permukaan benda yang terkena percikan droplet tersebut (WHO, 2020). Penularan Covid-19 yang sangat masif ini menyebabkan mahasiswa khawatir tertular saat mereka harus keluar dari tempat tinggal.

Pemerintah juga menggalakkan penggunaan masker bagi semua orang yang sehat maupun yang sakit untuk mengurangi penularan Covid-19. Selain itu himbauan untuk menjaga jarak dan social distancing juga diberlakukan untuk membantu mencegah terjadinya penularan Covid-19 secara cepat (Fong, 2020).

Social distancing merupakan salah satu langkah pencegahan dan pengendalian menyebarnya Covid-19 dengan cara membatasi kunjungan ke tempat ramai, dan mengutamakan stay at home (Adrian, 2020). Beberapa waktu terakhir WHO mengubah 
penyebutan social distancing menjadi physical distancing karena yang dijaga adalah jarak fisik bukan jarak sosial. Hubungan sosial masih bisa terhubung dengan perantara teknologi. (Gloria, 2020). Meskipun istilahnya berbeda keduanya memiliki implikasi yang sama yaitu menghimbau masyarakat untuk tinggal di rumah, belajar dan bekerja dari rumah serta hanya keluar rumah untuk keperluan yang benar-benar mendesak.

Pelaksanaan physical distancing ini tentu membutuhkan adaptasi bagi berbagai pihak. Terutama bagi mahasiswa yang harus melakukan perkuliahan secara daring semenjak mewabahnya virus corona.

Keterbatasan untuk melakukan aktivitas di luar serta kecemasan tertular virus Covid19 yang ditunjukkan oleh sebagian besar responden pada pertanyaan nomor 2 yang mewakili hal tersebut memberikan gambaran bahwa wabah ini menimbulkan stres tersendiri bagi mahasiswa.

Perkuliahan daring akibat mewabahnya virus Covid-19 ternyata juga menimbulkan stres tersendiri bagi mahasiswa. Hal ini tampak pada distribusi skor rata-rata tertinggi jawaban kuesioner pada nomor 19 yang berkaitan dengan kesulitan memahami materi pada perkuliahan daring.

Di Indonesia, kuliah daring terbilang sangat baru. Mungkin banyak dosen dan mahasiswa yang belum pernah melakukannya sebelumnya. Perkuliahan yang biasanya dilakukan secara tatap muka, sekarang terpaksa dilakukan secara daring. Hal ini tentu menjadi beban tersendiri dan membutuhkan adaptasi. (Rania, 2020)

Perkuliahan daring memang membutuhkan adaptasi dan usaha agar dapat berjalan lancar. Mulai dari belajar aplikasi yang menunjang perkuliahan daring seperti zoom, google classroom, edmodo dan beragam aplikasi belajar dan conference lainnya. Perkuliahan daring juga membutuhkan akses internet yang mumpuni. Selain itu dibutuhkan usaha untuk memahami materi yang biasanya disampaikan secara lisan menjadi tulisan dan video atau live streaming.

\section{Kesimpulan}

Wabah Covid-19 menimbulkan banyak perubahan dan tekanan. Kekhawatiran terhadap penularan Covid-19 menjadi stressor tersendiri, kemudian kesulitan memahami materi perkuliahan daring juga menimbulkan stressor tambahan bagi mahasiswa. Ditambah dengan keterbatasan aktivitas dan kebosanan selama stay at home juga menjadi stressor tambahan yang menimbulkan stres bagi mahasiswa selama pandemic Covid-19 ini.

\section{Saran}

Diperlukan semangat dan tekad yang kuat bagi dosen dan mahasiswa agar dapat melaksanakan pembelajaran daring secara efektif. Kondisi yang tidak nyaman bagi semua pihak ini perlu disikapi dengan bijaksana dan lapang dada.

Saran bagi mahasiswa untuk mereduksi stres yaitu dengan melakukan hobi atau aktivitas menyenangkan yang bisa dilakukan dari rumah.

\section{Ucapan Terima Kasih}

Terima kasih kepada Stikes Karya Husada Kediri yang telah memberikan kesempatan untuk melaksanakan penelitian ini. Terima kasih kepada seluruh responden yang telah berpartisipasi dalam penelitian ini. Serta ucapan terima kasih kepada Stikes Pamenang yang memberikan kesempatan publikasi artikel penelitian ini.

\section{Daftar Pustaka}

Adrian,2020. Pentingnya Menerapkan Social Distancing Demi Mencegah COVID-19 Alodokter. (n.d.). Retrieved April 28, 2020, from https://www.alodokter.com/pentingnyamenerapkan-social-distancing-demimencegah-covid-19

Fong, 2020. Fong, M. W., Gao, H., Wong, J. Y., Xiao, J., Shiu, E. Y. C., Ryu, S., \& Cowling, B. J. (2020). Nonpharmaceutical Measures for Pandemic Influenza in Nonhealthcare Settings-Social Distancing Measures. Emerging Infectious Diseases, 26(5). https://doi.org/10.3201/eid2605.190995

Gloria, 2020. WHO Ubah Social Distancing Jadi Physical Distancing, Apa Maksudnya? Halaman 2 - Kompas.com. (n.d.). Retrieved April 29, 2020, from https://www.kompas.com/sains/read/2020/03/ 24/120000023/who-ubah-social-distancingjadi-physical-distancing-apa-maksudnya?page $=2$

Rania, 2020. Konsep Kuliah Online Masih Sering Gagal Dipahami. Di Satu Sisi, Praktik Ini Memang Masih Baru sih. (n.d.). Retrieved April 29, 2020, from https://www.hipwee.com/feature/kuliahonline-karena-virus-corona/ 
Kemenkes, 2020. Beranda | Gugus Tugas Percepatan Penanganan COVID-19. (n.d.). Retrieved April 28, 2020, from https://www.covid19.go.id/

Tabroni, 2020. Trend Kuliah Daring di Tengah Wabah Virus Corona | Republika Online. (n.d.). Retrieved April 28, 2020, from https://republika.co.id/berita/q85myf469/tren d-kuliah-daring-di-tengah-wabah-viruscorona

WHO, 2020. Pertanyaan jawaban terkait COVID19 untuk publik. (n.d.). Retrieved April 28, 2020, from https://www.who.int/indonesia/news/novelcoronavirus/qa-for-public 